\title{
Johtajuus tieteiden rajapinnoissa
}

Juha Perttula \& Antti Syväjärvi (toim.) (2012):

Johtamisen psykologia. Ihmisten johtaminen muuttuvassa työelämässä.

PS-kustannus, Juva. $243 \mathrm{~s}$.

ISBN: 978-952-451-568-9

LAPIN YLIOPISTON professorit Juha Perttula (psykologia) ja Antti Syväjärvi (hallintotiede) ovat tarttuneet haasteelliseen tehtävään pyrkiessään "tarkastelemaan ihmistä erityisesti kahdesta näkökulmasta: kokevina ja toisten kanssa yhdessä toimivina”.

He ovat toimittaneet Johtamisen psykologia -kirjan puhuttelemaan erilaisissa asemissa toimivia esimiehiä, kokeneita ammattijohtajia ja ihmisestä työelämässä kiinnostuneita opiskelijoita, mutta myös muita ihmisten johtamisesta kokonaisvaltaisesti kiinnostuneita. Tavoitteena ovat olleet "rajanylitykset", joista olennaisimpana odottaisi olevan psykologian ja hallintotieteen näkökulmien yhdistämisen.

Kunnianhimoisten tavoitteiden saavuttamisessa teos ei kuitenkaan kaikilta osin onnistu. Johtamisen psykologia ei ole sellainen "ensimmäinen suomenkielinen teos, jossa johtamisen ja psykologian tietoperustaa yhdistetään systemaattiseksi kokonaisesitykseksi”, kuten kirjoittajat lupaavat.

Perttula ja Syväjärvi ovat keränneet kirjoittajiksi kymmenen henkilöä Lapin, Oulun ja Jyväskylän yliopistoista sekä tutkimus- ja kehittämisjohtajan, projektipäällikön ja yhden kansanedustajan.
Kirjoittajista seitsemän on lähtökohdiltaan hallintotieteilijöitä, yksi oikeustieteilijä, yksi psykologi ja yksi terveyshallintotieteilijä. Tämä moninaisuus näkyy lopputuloksessa osittain toisiinsa liittymättöminä kannanottoina.

\section{ORGANISAATIOT TODELLISIA VAI KOKEMUKSELLISIA?}

Luvussa Kokemuksellinen organisaatio (Tökkäri) on tarkoituksena suhtautua kriittisesti vallitsevaan näkökulmaan ja tarkastella, miten organisaatiot todellistuvat jäsenilleen heidän kokemuksissaan työyhteisöstään ja työstään.

Vallitsevan näkökulman kritiikki on usein ongelmallista: tullaan yksinkertaistaneeksi asioita ja väittäneeksi, että joku näin oikeasti uskoo. Ajatus kokemuksellisuuden merkityksestä ei ole uusi, vaikkakin tärkeä. Kokemuksellisuuden ja tulkinnallisuuden korostaminen ja muistaminen arjessa ovat tärkeitä, mutta niin vaikeita asioita.

Kun Tökkäri toteaa, "että ihmisten välisen kanssakäymisen ja heidän kokemustensa ulkopuolelle ei jää organisaatiossa mitään”, olikin mielenkiintoista lukea Paasivaaran luku Yksilöistä työyhteisöksi, jossa terveyshallintotieteilijä tarkastelee yksilön ja työyhteisön suhdetta. Paasivaara pukee saman asian sanoiksi näin: "Ilman ihmisiä työyhteisö olisi vain hengetön infrastruktuuri, joka ei uudista toimintaansa”.

Hänen mukaansa "työyhteisönäkökulmalla tarkoitetaan ensisijaisesti rakenteellista ja sosiaalista verkostoa, jota luodaan päämääriin ja tavoitteisiin pyrkimiseksi. Keskeistä on se, että työyhteisöä luodaan perustehtävää varten”.

Vaikuttaa siis siltä, että Paasivaaralle jää jotakin vielä ihmisten kanssakäymisen ja heidän kokemustensa ulkopuolelle. Kirjoittaja selventää, että "toimivalla työyhteisöllä tulee olla selkeä rakenne, jolla on omat tavoitteet, toimintamallit ja kehittämistyö, määrätty johtaja ja henkilöstö. Työyhteisön tavoitteellisuus syntyy virallisesta tarkoitusperästä”.

\section{JOHTAJUUDEN}

HAHMOTTAMISTA KÄSITTEITÄ ANALYSOIMALLA

Luku Ihminen ja vuorovaikutus muutoksessa - kompleksisuus ja muutosten hallinta (Laitinen ja Stenvall) esittelee nimensä mukaisesti kompleksisuusajattelua ja siihen liittyviä käsitteitä, erityisesti CRP:tä (complex responsive process).

Johtopäätöksissään tekijät sanovat ”pitävänsä kompleksisen 


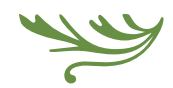

responsiivisen prosessin teoriaa prosessisosiologisesti ja pragmatistis-sosiaalipsykologisesti rakentuneena vuorovaikutusta ja ryhmäprosessia painottavana teoriana”.

Tämä kuvaa hyvin koko luvun luonnetta. On epätodennäköistä, että johtamisen käytännöistä tai niiden kehittämisestä kiinnostunut lukija saisi omalle työlleen merkittäviä lisäideoita lukiessaan, kuinka "...ongelma heijastelee sitä postmodernien organisaatioteoreetikkojen tunnistamaa systeemikeskeistä organisaatiotutkimusta, jota on vaivannut ihmisen poissaolo ja esineellistyminen eli se, miten ihminen nähdään joinakin yksittäisinä tutkimuspiirteinä tai organisaation rakennetekijöinä”.

Lukija saa sen käsityksen (kokemuksen), että kirjoittajat ovat kiinnostuneempia tarkastelemaan eri käsitteiden välisiä yhteyksiä ja nimityksiä kuin niiden yhteyksiä johtamiseen ja sen mahdollisuuksiin työelämässä, erityisesti muutoksessa.

Luvun 4 otsikko Itsensä johtaminen (Perttula) ohjaa lukijan odottamaan pohdintaa itsensä johtamisen tärkeydestä tai menetelmistä ja niiden yhteydestä johtamiseen. Vähänkin pragmaatti- sesti ja empiirisesti suuntautuva lukija kuitenkin pettyy. Perttula lähtee pohtimaan käsitteiden 'ihmiskäsitys' ja 'ihmiskuva' yhteyttä käsitteisiin 'johtaminen' ja 'itsensä johtaminen'. Mielenkiintoisia ovat kuitenkin Perttulan esittämät kysymykset: Mitä johdettavaa ihmisessä on, ja mikä merkitys itsensä johtamisella on ihmisten johtamisessa?

Perttula tarkastelee neljää ihmiskäsitystä (essentialistinen, naturalistinen, kulturalistinen ja eksistentialistinen) ja näistä lähtevää tulkintaa ihmisten johtamiseen ja itsensä johtamiseen Kanniston (1994) tapaan. Jos edellä esitetystä poiketen ajattelee, että kullakin ihmiskäsityksellä on samanaikaisesti annettavaa johtamiselle ja itsensä johtamiselle, osoittaa Perttulan tulkinta, että kyse on neljästä arkipäivässä toisiaan täydentävästä tekijästä.

Puhutteleva oli havainto, jonka mukaan "yksilön valinnat koskevat toisten elämää ja että tietoisuus tästä on itsensä johtamisen kulmakivi”. Sopiikin miettiä, mihin kaikkeen tämä päätelmä johtaa.

\section{JOHTAJUUTTA HIERARKIAN \\ ERI TASOILLA}

Pietiläinen ja Kesti esittelevät luvussa Johtamisen tilanneherkistymi- nen ja asiantuntijuus ammatillisia kompetensseja, erityisesti johtamiskompetensseja. Asetelma on mielenkiintoinen: "Mitä ammatillisia kompetensseja kompleksisen toimintaympäristön erilaisissa tilanteissa tarvitaan?".

Tekijät lupaavat tarkastella "johtamisen tilanneherkistymistä organisaatioiden toimintaympäristöjen kompleksisuuden näkökulmasta”. Kompetensseista rakentuvaa systeemiälykkyyden mallin käsitettä käytetään apuna organisaatiosysteemin toiminnan ja kehittämisen ymmärtämiseen. Mutta mitä lyhyesti tarkoitetaan systeemiälykkyyden mallilla?

Pietiläisen ja Kestin mukaan muun muassa sitä, että "organisaation ylin johtaminen on eriytetty työyhteisöryhmien lähiesimiestoiminnasta. Johto määrittää organisaation vision ja strategian sekä luo edellytykset organisaation kehittymiselle". Kirjoittajat esittelevät erilaisia myönteisiä organisaation ja työyhteisön ominaisuuksia ja päätyvät toteamaan, että ”älykkäässä organisaatiossa johto, esimiehet ja työntekijät toimivat yhdessä älykkäästi”. Hiemankaan kyynisyyteen taipuva lukija ei löydä tästä päättelystä merkittävää lisäarvoa johtamiseen tai organisaation ymmärtämiseen. 


\title{
SEN SIJAAN, ETTÄ JOHTAMINEN
}

\author{
KESKITTYY ONGELMIIN, \\ PITÄISI SIINÄ KOROSTAA
}

JOHTAJUUDEN VOIMAVARANA MYÖNTEISYYS

Syväjärvi ja Vakkala asettavat luvussa Psykologinen johtamisorientaatio - positivisuuden merkitys ihmisten johtamisessa tavoitteekseen esitellä ihmisläheistä johtajuutta, joka tekijöiden mukaan on psykologisen johtamisorientaation keskeinen ilmentymä. Sen sijaan, että johtaminen keskittyy ongelmiin, pitäisi siinä korostaa mahdollisuuksia ja positiivisia asioita. Tekijöiden mukaan "positiivisuus johtajuudessa tavoittelee myönteisyyttä ihmisten johtamiseen, mutta samalla onnellisempia ja sensitiivisempiä työyhteisöjä”. Lisäksi "psykologisessa johtamisorientaatiossa on pyrkimyksenä ymmärtää ja osoittaa, mikä saa yksilön, työyhteisön ja laajemmin organisaation toimimaan tietyllä tavalla sekä miten niiden muodostamaa kokonaisuutta voi johtaa”.

"Ihmisläheinen, psykologinen johtajuus elää hetkessä ja ratkoo ongelmia tilannekohtaisesti ja vuorovaikutteisesti, mutta tavoitteista ja rajoista kiinni pitäen" (Vakkala, 2012, Syväjärven ja Vakkalan mukaan). Tekijöiden mielestä ihmisläheinen johtamisorientaatio eroaa juuri tässä perinteisestä, joka "näkee johtami- sen suunnitelmallisena ja hallittavana kokonaisuutena”.

Eron tekeminen tuntuu tarpeettomalta. Toiminnan hierarkkisesta näkökulmasta katsoen kyse voi olla eri tasoilla tapahtuvasta johtamisesta. Eihän kumpikaan orientaatio yksinään ole riittävä. Ei johtaminen, joka aina lopulta on ihmisten johtamista, voi olla vain joko suunnittelua ja hallintaa tai vain tilannekohtaista ongelmien ratkaisua. Tähän tekijätkin päätyvät, vaikka eivät tarkastele asiaa toiminnan hierarkian näkökulmasta, joka olisi varsin luonnollinen jäsennystapa.

Syväjärvi ja Vakkala kirjoittavat, että "johtajuuden on huomioitava ihmisen situaatio, jolloin sekä työsidonnaiset että työn ulkopuoliset asiat ovat yhdessä läsnä työtä tekevän ihmisen kokemuksissa. Toisaalta johtajuudessa on käsiteltävä työhyvinvoinnin sijasta työvointia, joka yhdistää työhön liittyvän pahoinvoinnin ja hyvinvoinnin teemat. Kolmanneksi johtajuuden on tarjottava konkreettisia vastauksia kahteen edelliseen kohtaan, koska johtajuuden tulee toimia siinä kokonaisuudessa, johon sekä negatiivinen että positiivinen kuuluvat".

Tavoitteet ovat siis selkeät, samoin positiivisen johtajuuden keskeiset painotukset. "Kyse on siitä, miten positiivisuutta tunnistetaan, vahvistetaan ja kehitetään johtajuuden avulla yksilöiden ja yhteisöjen hyväksi”. Syväjärvi ja Vakkala toteavat vielä, että "kriittisen ja reflektiivisen otteen merkitys on suuri johtajuudelle, koska myös positiivinen johtajuus on kohdattava puutteineen ja hyveineen".

Koko teoksen keskeisen näkemyksen tiivistää Jungner kommenttipuheenvuorossaan: "Tärkein ominaisuus niin johtajilla kuin johdettavilla on kuitenkin vahva usko yksittäisen ihmisen henkiseen kasvuun”.

Teos haastaa lukijaa tekemään päätelmiä johtajuudesta eri tieteenalojen näkökulmista. Kirjoittajat eivät anna valmiita ratkaisuja. Teosta voi suositella erityisesti niille, jotka haluavat jäsentää johtajuutta käsitteellisellä tasolla, tieteiden rajat ylittävänä ilmiönä.

\section{Soili Keskinen}

PsT, Kasvatustieteen professori, Työ- ja organisaatiopsykologian dosentti Turun yliopisto 